\title{
Häufiger verwendete Abkürzungen
}

$\mathrm{AE}=$ L'année épigraphique

BCAR $=$ Bullettino della Commissione Archeologica Comunale di Roma

CIFM $=$ Corpus des inscriptions de la France médiévale

ChLA $=$ Chartae Latinae Antiquiores

$\mathrm{CIL}=$ Corpus Inscriptionum Latinarum

CSIR $=$ Corpus Signorum Imperii Romani

Dessau $=$ Inscriptiones Latinae Selectae (auch ILS)

DI $=$ Die deutschen Inschriften des Mittelalters und der Frühen Neuzeit

$\mathrm{IG}=$ Inscriptiones Graecae

IGLSyr $=$ Les inscriptions grecques et latines de la Syrie

IGUR = Inscriptiones Graecae Urbis Romae

ILAlg = Inscriptions latines d'Algérie

IvPriene $=$ Die Inschriften von Priene (Inschriften griechischer Städte aus Kleinasien 69)

IvPriene 1906 = Friedrich Hiller von Gaertringen, Inschriften von Priene, Berlin 1906

IvSagalassos I $=$ Die Inschriften von Sagalassos I (Inschriften griechischer Städte aus Kleinasien 70)

$\mathrm{JbAC}=$ Jahrbücher für Antike und Christentum

LTUR = Lexicon Topographicum Urbis Romae (1993-2016)

OCR $=$ Optical Character Recognition (optische Texterkennung)

OGIS $=$ Orientis Graeci Inscriptiones Selectae

https://doi.org/10.1515/9783110753684-202 
P. Cair. Zen. = Catalogue général des antiquités égyptiennes du Musée de Cairo. Zenon Papyri, Kairo (1925-1940)

$\mathrm{PIR}^{2}=$ Prosopographia Imperii Romani² (1933-2015)

PLRE $=$ Prospography of the Later Roman Empire

P. Oxy. $=$ The Oxyrhynchus Papyri

PSI = Papiri greci e latini (Pubblicazioni della Società Italiana per la ricerca dei Papiri greci e latini in Egitto)

RGZM = Barbara Pferdehirt, Römische Militärdiplome und Entlassungsurkunden in der Sammlung des Römisch-Germanischen Zentralmuseums (Kataloge Vor- und Frühgeschichtlicher Altertümer 37,1-2), Mainz 2004

RIB = The Roman Inscriptions of Britain, https://romaninscriptionsofbritain.org/

RMD = Roman Military Diplomas, 5 Bände, London 1978-2006

Sammelbuch $=$ Sammelbuch griechischer Urkunden aus Ägypten, Band 1, Berlin 1915 (Band 29, Wiesbaden 2013)

SH $=$ Supplementum Hellenisticum

Syll. $^{3}=$ Sylloge Inscriptionum Graecarum ${ }^{3}$, ed. W. Dittenberger

Tab. Pomp. Sulp. $=$ Tabulae Pompeianae Sulpiciorum

Tab. Vindol. $=$ The Vindolanda Tablets (tabulae Vindolandenses II-IV), London 1994-2010, danach https://romaninscriptionsofbritain.org/inscriptions/TabVindol890

Tab. Vindonissa = Die Schreibtafeln von Vindonissa, ed. Michael Speidel, Brugg 1996 WIAG $=$ Wissensaggregator Mittelalter und Frühe Neuzeit

ZPE = Zeitschrift für Papyrologie und Epigraphik 